\title{
Контроль патогенных микроорганизмов в кормах повысит продуктивность кур-несушек
}

\author{
Моисеенко Н.Н., менеджер отдела продаж сырья \\ Компания «Коудайс МКорма»
}

Аннотация: Абтор обращает Внимание на проблему контаминации патогенами кормов и кормовых компонентов для несушек. В статье перечисляются различные способы деконтаминации, применяемые 6 настоящее время, отмечаются их достоинства и недостатки. Основываясь на международном опыте и произбодственных испытаниях, автор делает вывод, что кормовой дезинфектант «Термин-8» является наиболее эффективным средством для борьбы с патогенами б кормах и кормовых ингредиентах.

Ключебые слова: сальмонелла, клостридия, бактерии, контаминация кормов, куры-несуики, качество кормов, биобезопасность, продуктивные показатели.

Микробная контаминация - один из основных факторов, влияющих на качество кормов, который не только снижает экономическую эффективность производства продукции животноводства, но и представляет реальную угрозу здоровью потребителей этой продукции, что, безусловно, требует тщательного контроля данного показателя.

Такие факторы, как отсутствие термической обработки кормов и продолжительный период эксплуатации несушек, увеличивают риск неблагоприятного воздей-ствия окружающей среды, повышая вероятность встречи с патогенами. В связи с этим важно предпринять все возможные меры по обеспечению полного раскрытия генетического потенциала птицы, начиная с суточного возраста цыпленка.

\section{Скармливание рационов, сво-} бодных от патогенов, повышает яйценоскость и сохранность несушек, удерживая данные показатели на стабильно высоком уровне.

Первые 16 недель являются наиболее важными для дальнейшего развития птицы: в этом возрасте энергия направлена в большей степени на рост, поэтому птица не может в полной мере защитить себя от патогенов, переносимых с кормом. Скармливание контаминированного корма на этой стадии может повлечь за собой снижение конверсии корма и среднесуточного прироста живой массы [1].

Степень негативного влияния контаминированных кормов на птицу зависит от количества бактерий и их видовой принадлежности. Патогенные бактерии, встреча- ющиеся в кормах, можно условно разделить на две группы: бактерии, производящие токсичные побочные продукты, и бактерии, внедряющиеся в клетки организма хозяина [2].

K первой группе относятся такие патогенные микроорганизмы, как клостридия и кишечная палочка; они вырабатывают токсины, которые повреждают клетки кишечного тракта, нарушая их нормальный метаболизм.

Бактерии из второй группы, проникая в клетки эпителия желудочно-кишечного тракта, вызывают кровоизлияния и некроз, оказывают чрезмерную нагрузку на иммунную систему. Из-за уменьшения длины ворсинок и сокращения их количества уменьшается площадь поглощающей поверхности кишечника, что, в свою оче- 
редь, приводит к снижению всасывания питательных веществ и увеличению секреции жидкости. Как правило, это становится причиной низкой продуктивности, особенно это заметно на молодой птице [3].

Кроме непосредственного воздействия на желудочно-кишечный тракт птицы, бактерии также оказывают опосредованное негативное влияние. Патогенные микроорганизмы, попадающие в кишечник через корма, создают опасную конкуренцию полезным бактериям, имеющим большое значение для роста и развития молодой птицы. Такие бактерии как лактобациллы, которые производят короткоцепочечные жирные кислоты, необходимые для развития птицы, не выдерживают конкуренции со стороны патогенных микроорганизмов. Жирные кислоты, производимые лактобациллами, служат источником энергии, улучшают рост и деление клеток, стимулируют образование слизи бокаловидными клетками и повышают иммунитет. Снижение всасывающей площади кишечника и конкуренция патогенов с полезными бактериями, кроме всего прочего, будут влиять на яичную продуктивность [4].

Загрязненный корм может оказывать влияние не сразу, отразившись на продуктивности птицы в будущем. Если при достижении 16-недельного возраста птица не имеет каких-либо заметных откло- нений по конверсии корма, среднесуточному приросту или сохранности, производитель может ошибочно полагать, что использует чистые корма, или что уровень бакобсемененности кормов не имеет большого значения [5].

По окончании 16-недельного возраста несушек переводят в другие помещения, где на протяжении 72-80 недель они будут эксплуатироваться, пока их яичная продуктивность не снизится. Это довольно длительный период, поэтому крайне важно, чтобы птица на всем его протяжении оставалась в здоровом состоянии. При этом стресс, вызванный переводом птицы из одного птичника в другой, всегда пагубно сказывается на иммунной системе. Таким образом, птица становится более восприимчивой к инфекциям, в то время как бактерии, которые присутствуют в кишечнике во время перевода из одного птичника в другой, неочевидные в своем проявлении, в критический момент могут оказать свое вредное воздействие.

По словам доктора К. Ричардсона, одним из наиболее распространенных заболеваний, наблюдаемых у кур-несушек, при переводе из одного птичника в другой, является желточный перитонит. Болезнь возникает при одновременном присутствии стресса, вызванного переводом в другой птичник, и наличии в кормах патогена E. coli. Брюшная полость вос- паляется, оболочка вокруг желтка формируется некорректно. Желток оседает внутри полости, не продвигается вниз по яйцеводу, находясь внутри оболочки. Осев в брюшной полости, желток создает питательную среду для инфекции. Как правило, больная птица принимает «позу пингвина», пытаясь сбросить избыточное давление, оказываемое на ее дыхательную систему $[6,7]$.

Кроме E. coli и других патогенов, влияющих на продуктивность несушек, в кормах может присутствовать сальмонелла, которая вызывает серьезные проблемы со здоровьем кишечника птицы, а также влияет на безопасность конечного продукта - пищевого яйца.

Как известно, сальмонеллу трудно обнаружить в корме, но исследования показывают, что данный патоген широко распространен во всех без исключения видах кормового сырья. В общей массе корма или кормового сырья сальмонелла часто скрывается, локализуясь в небольших участках, которые могут легко остаться незамеченными.

Определяя корма и кормовое сырье как одну из ключевых точек в обеспечении биобезопасности производства, мы не только повышаем производственные показатели, но и снижаем риски для потребителей. Если сальмонелла присутствует в желудочнокишечном тракте птицы, всегда 
существует вероятность, что во время яйцекладки, при прохождении яйца через яйцевод, яичная скорлупа будет заражена патогеном.

Для решения проблемы контаминации кормов применяются различные способы, одним из самых распространенных является использование органических кислот, но их использование имеет ряд недостатков [8]:

- По данным ряда авторов $[9,10]$, для эффективной защиты уровень рН в кормах необходимо понизить до значений ниже 5. Для достижения такого результата дозировка кислот должна быть на уровне 5-10 кг/т корма. Препараты на основе органических кислот чаще всего применяются в концентрациях 1-3 кг/т, что является недостаточным, поскольку при такой норме ввода замедляется лишь рост бактерий, погибает только их незначительная часть;

- Показано, что включение в корм смеси муравьиной (68\%) и пропионовой (20\%) кислот в дозах 6, 8 и 12 кг/т корма не изменяло уровень рН в зобе цыплят: эти кислоты всасывались раньше, чем достигали мышечного желудка [11]. Подобным образом было установлено, что $\mathrm{pH}$ зоба цыпленка находится в районе 4,6-5,3 и не изменяется при потреблении корма, содержащего пропионовую кислоту в дозе 5 кг/т [12]. Таким образом, идея о том, что органические кислоты способны снижать уро- вень $\mathrm{pH}$ в желудочно-кишечном тракте птицы, тем самым защищая организм от патогенной микрофлоры, не находит подтверждения.

- Ряд ученых (см. [13]) вводят термин «маскирование» («masking») в отношении взаимодействия органических кислот с микроорганизмами. Исследователи считают, что органические кислоты «маскируют» бактерии, и существующие тесты не всегда способны выявить полную картину, тем самым вводя исследователей в заблуждение.

Эффективным способом борьбы с патогенами в кормовых компонентах или комбикормах принято считать термическую обработку, но данный способ не гарантирует защиту от повторной контаминации.

Отталкиваясь от обозначенных проблем, связанных с органическими кислотами и термической обработкой, компания Anitox разработала препарат Термин-8 (Termin-8), который основан на формальдегиде, терпенах и пропионовой кислоте. Препарат эффективен против всех групп

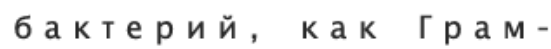
отрицательных, так и Грамположительных. Термин-8 апробирован и используется ведущими мировыми производителями сельскохозяйственной продукции, кормов, сырья и племенной птицы.

В 1999 г. Андерсон и Ричар- дсон провели испытания Термина8 на несушках кросса Hy-Line W36 и показали, что у птицы в возрасте от 17 до 66 недель существенно улучшились основные показатели продуктивности: яйценоскость выросла с 270,1 до 274,7 яиц, суточный выход яйцемассы увеличился с 46,7 до 47,8 г, а количество энтеробактерий на поверхности скорлупы уменьшилось с 11600 до 1460 KOE/яйцо [5].

Для подтверждения иностранного опыта в российских условиях в период с 2015 по 2016 г. на предприятии N было проведено производственное испытание. Было задействовано 110029 голов курнесушек, 57445 голов в опытной группе и 52584 головы в контрольной. Продуктивный период длился с 17 до 74 недель жизни. Термин-8 применялся с 55-й недели и до конца продуктивного периода в дозировке 3 кг/т. В результате сохранность поголовья на конец эксперимента в опытной группе составила 91,55 против $84,02 \%$ в контрольной; в группе с Термином-8 было произведено больше яиц - 19053521 шт. против 17228747 шт. в контроле, что обеспечило снижение затрат корма на получение 10 яиц на $3,14 \%$, с 1,313 в контроле до 1,273 кг.

По итогам проведенных испытаний, основываясь на многолетнем международном опыте работы, можно сделать вывод, что Термин-8 является эффективным сре- 
дством для борьбы с бактериями в кормах. Термин-8 не только очищает и защищает корма и кормовые средства, но и обеспечивает значительное повышение производственных показателей, увеличивая рентабельность производства. При этом обеспечиваются высокие стандарты биобезопасности конечной продукции, что особенно важно для экспортноориентированных производителей.

\section{Литература}

1. Tabib Z., Jones F.T., Hamilton P.B. Microbiological quality of poultry feed and ingredients // Poult. Sci. - 1981. - V. 60, No 7. - P. 1392-1397.

2. Maciorowski K.G., Herrera P., Jones F.T., Pillai S.D., Ricke S.C. Effects on poultry and livestock of feed contamination with bacteria and fungi // Anim. Feed Sci. Technol. - 2007. - V. 133. - P. 109-136.

3. Mani-Lypez E., Garcha H.S., LypezMalo A.. 2012. Organic acids as antimicrobials to control Salmonella in meat and poultry products // Food Res.
Intl. - 2012. - V. 45, No 2. - P. 713-721.

4. Sekirov I., Russell S.L., Caetano L., Antunes M., Finlay B.B. Gut microbiota in health and disease // Physiol. Rev. 2010. - V. 90. - P. 859-904.

5. Anderson K.E., Richardson K.E. Effect of Termin-8 compound on the microbiological and physical quality of shell eggs from commercial laying chickens // 21 st Ann. Meet. Southern Poultry Sci. Assoc. 2000.

6. Beckman B. Current perspectives on peritonitis. 2006. [Эл. ресурс: http://www.zootecnicainternational.co $\mathrm{m} /$ article-archive/veterinary/909current-perspectives-onperitonitis.html (доступ 16.07.2012).]

7. Vandekerchove D., De Herdt P. Colibacillosis in caged layer hens: Characteristics of the disease and the aetiological agent // Avian Pathol.2004. - V. 33, No 2. - P. $117-25$

8. Моисеенко Н.Н. Деконтаминация кормов // Птицеводство. - 2016. - № 10. - C. 19-22.

9. Wales A.D., Allen V.M., Davies R.H. Chemical treatment of animal feed and water for the control of Salmonella // Foodborne Pathogens and Disease. 2010. - V. 7. - P. 3-15.

10. Berge A.C., Wierup M. Nutritional strategies to combat Salmonella in monogastric food animal production // Animal. -2012.- V. 6, No 4. - P. 557-564. 11. Thompson J.L., Hinton M. Antibacterial activity of formic and propionic acids in the diet of hens on Salmonellas in the crop // Br. Poult. Sci. 1997. - V. 38. - P. 59-65.

12. Hume M.E., Corrier D.E., Ivie G.W., Deloach J.R. Metabolism of [14C] propionic acid in broiler chicks // Poult. Sci. - 1993. - V. 72. - P. 786-793.

13. Carrique-Mas J.J., Bedford S., Davies R.H. Organic acid and formaldehyde treatment of animal feeds to control Salmonella: efficacy and masking during culture // J. Appl. Microbiol. - 2007. - V. 103, No 1.- P. 88-96

\section{Для контакта с автором:}

Моисеенко Николай Николаевич

E-mail: nmoiseenko@kmkorma.ru Тел.: 8 (495) 645-21-59

\title{
The Control of Pathogenic Microbial Strains in Feeds Can Improve Productivity in Laying Hens
}

\author{
Moiseyenko N.N.
}

Koudijs MKorma Co.

Summary: The problem of contamination of feed ingredients and compound feeds with pathogens is reviewed; different practical methods of decontamination, their advantages and disadvantages are highlighted. From the standpoint of international research data and recent test in conditions of a Russian commercial egg-producing enterprise the author concludes that disinfectant Termin-8 is a highly effective preparation for the decontamination of feed ingredients and feeds.

Key words: Salmonella, Clostridia, bacteria, feed contamination, laying hens, feed quality, biosecurity, productive performance. 